Pelita Masyarakat, 2(1) September, $2020 \quad$ ISSN 2686-3200 (Online)

DOI: https://doi.org/10.31289/pelitamasyarakat.v2i1.4194

\title{
Pengabdian Kepada Masyarakat pada Usaha Keripik Pisang Nangka Desa Limau Manis Kecamatan Tanjung Morawa Kabupaten Deli Serdang
}

\section{Community Service in Banana Chips Business, Limau Manis Village, Tanjung Morawa District, Deli Serdang Regency}

\author{
Ninny Siregar, Kamaluddin Lubis \& Nuril Mahda* \\ Program Studi Teknik Sipil, Fakultas Teknik, Universitas Medan Area, Indonesia \\ Diterima: 27 Agustus 2020 ; Disetujui: 29 September 2020 ; Dipublish: 16 September 2020
}

*Email: $\underline{\text { ninnvsiregar27@gmail.com }}$

\begin{abstract}
Abstrak
Usaha yang dilakukan oleh Ibu Maimunah adalah industri rumah tangga (Home Industry) yang berada di Jl. Hasan Tua Dusun III B Desa Limau Manis Kecamatan Tanjung Morawa Kabupaten Deli Serdang. Usaha ini memiliki potensi yang luar biasa karena produksi berupa keripik pisang yang berasal dari buah pisang nangka dibuat melalui proses pengolahan yang sederhana. Dengan adanya bantuan mesin pengiris pisang maka produksi keripik pisang nangka meningkat, dari 50-60 kg/hari dengan waktu kerja 8 jam/hari menjadi 150-200 kg/hari. Hal tersebut dapat dilakukan dengan meningkatkan produktivitas pada sistem manajemen produksi dan sistem manajemen pemasaran.
\end{abstract}

Kata Kunci: Usaha Keripik Pisang Nangka, Produktivitas, Sistem Manajemen Produksi.

\section{Abstract}

The business carried out by Ms. Maimunah is a home industry located on Jl. Hasan Tua Dusun III B Limau Manis Village, Tanjung Morawa District, Deli Serdang Regency. This business has tremendous potential because the production of banana chips derived from jackfruit bananas is made through a simple processing process. With the help of banana slicing machines, the production of jackfruit banana chips has increased, from 50-60 kg / day with a working time of 8 hours / day to 150-200 kg / day. This can be done by increasing productivity in the production management system and marketing management system.

Keywords: Jackfruit Banana Chips Business, Productivity, Production Management System.

How to Cite: Siregar, N. Lubis, K. \& Mahda, N. (2020). PKM Pada Usaha Keripik Pisang Nangka Desa Limau Manis Kecamatan Tanjung Morawa Kabupaten Deli Serdang. Pelita Masyarakat: 2(1): 37-43. 
Ninny Siregar, Kamaluddin Lubis \& Nuril Mahda, PKM Pada Usaha Keripik Pisang Nangka Desa Limau Manis

\section{PENDAHULUAN}

Deli Serdang adalah salah satu kabupaten yang terdapat di Sumatera Utara. Dimana daerah memiliki banyak potensi dalam bidang pertanian seperti ubi, palawija dan pisang. Pisang adalah buah yang sangat bergizi yang merupakan sumber vitamin, mineral dan juga karbohidrat. Banyak manfaat dari Pisang itu sendiri, bisa dijadikan dijadikan buah meja, sale pisang, pure pisang, keripik pisang dan tepung pisang. Kulit pisang dapat dimanfaatkan untuk membuat cuka melalui proses fermentasi alkohol dan asam cuka. Daun pisang dipakai sebagi pembungkus berbagai macam makanan trandisional Indonesia. Batang pisang abaca diolah menjadi serat untuk pakaian, kertas dsb. Batang pisang yang telah dipotong kecil dan daun pisang dapat dijadikan makanan ternak ruminansia (domba, kambing) pada saat musim kemarau dimana rumput tidak/kurang tersedia (Khafiz, et al., 2018; Hasibuan, et al., 2017; Syahputra, et al., 2017; Harahap, 2019).

Di Desa Limau Manis Kecamatan Tanjung Morawa Kabupaten Deli Serdang, ada seorang ibu rumah tangga berusia 34 tahun yang berprofesi sebagai pengrajin/pengusaha bersama 5 orang anggotanya memanfaatkan potensi ini menjadi usaha rumahan pengoahan buah pisang nangka menjadi keripik pisang nangka dalam bentuk cemilan yang banyak diminati oleh masyarakat Sumatera Utara khususnya Kota Medan. Potensi pisang memiliki nilai tambah setelah dijadikan bahan olahan menjadi keripik pisang.

Menurut pengakuan dari Ibu Maimunah, usaha ini dilakukan turun temurun dari keluarga. Produk ini hanya dapat dijual di daerah Kabupaten Deli Serdang dan sektiarnya. Awalnya permintaan pasar pada saat itu tidak begitu banyak, namun seiring berjalannya waktu permintaan keripik pisang ini meningkat dari luar daerah Deli Serdang. Usaha ini hanya memproduksi sekitar 100 lusin bahan baku dalam sehari dari jumlah tersebut yang diperoleh. Adapun hasil keripik pisang sebanyak 15-20 kg/hari. Kondisi ini sebenarnya belum dapat memenuhi permintaan pasar yang seharusnya minimal $100 \mathrm{~kg}$ bahkan lebih perharinya.

Usaha ini memiliki potensi yang luar biasa dikarenakan rasanya yang gurih sebagai cemilan. Namun terlihat dari kondisi proses produksi industri rumah tangga ini masih memiliki masalah dalam hal ruang kerja yang kurang baik serta manajemen industri belum dikelola dengan baik. Oleh karena itu perlu kiranya untuk dikembangkan melalui kegiatan Program Kemitraan Masyarakat (PKM) untuk dilakukannya penyuluhan dan penerapan IPTEK khususnya dalam proses pengolahan bahan baku buah pisang nangka 
dari sisi tata ruang bangunan industri dan proses pengirisan yang masih menggunakan cara yang konvensional.

Ibu Maimunah memiliki masalah yang paling dominan adalah renovasi tempat usaha masih menggunakan lantai tanah, tidak memiliki dinding, beratapkan nipah sehingga kondisi tempat usaha kurang higienis dan belum memenuhi standard tempat usaha yang layak. Selain itu proses pengirisan buah pisang nangka menggunakan landasan kayu diberikan pisau pada posisi tengah lalu diiris dengan menggunakan tangan, hal ini dapat membahayakan operator dalam menjalankan proses pengirisan buah pisang nangka yang akan digoreng ke tahap selanjutnya.

Selain itu permasalahan yang dihadapi adalah proses pemasaran yang belum langsung ke konsumen akhir sehingga harga penjualan masih relatif rendah, dimana harga yang dijual ke agen sekitar Rp.26.000,-/kg padahal kalau dijual ecer dengan memanfaatkan outlet atau Media Online bisa mencapai Rp.40.000,-/kg. Sebenarnya kedua mitra ini saling memiliki keterkaitan untuk dikembangkan, oleh karena itu permasalahan utama yang dihadapi oleh mitra ini adalah : 1) Proses produksi pisang nangka memiliki tempat yang tidak layak dalam hal ruang kerja. Teknologi yang digunakan sangat sederhana sekali dalam hal cara pengolahan proses pengirisan menggunakan cara-cara manual; 2) Pengetahuan IPTEK belum maksimal dimiliki oleh pengrajin dan belum adanya lembaga yang memberi penyuluhan tentang IPTEK yang sesuai dengan kebutuhan pengusaha.

\section{ANALISIS SITUASIONAL}

Menurut pengakuan Ibu Maimunah sebagai pemilik usaha, mengatakan masalah yang paling dominan adalah renovasi tempat usaha masih menggunakan lantai tanah, tidak memiliki dinding, beratapkan nipah sehingga kondisi tempat usaha kurang higienis dan belum memenuhi standard tempat usaha yang layak. Selain itu proses pengirisan buah pisang nangka menggunakan landasan kayu diberikan pisau pada posisi tengah lalu diiris dengan menggunakan tangan, hal ini dapat membahayakan operator dalam menjalankan proses pengirisan buah pisang nangka yang akan digoreng ke tahap selanjutnya.

Selain itu permasalahan yang dihadapi adalah proses pemasaran yang belum langsung ke konsumen akhir sehingga harga penjualan masih relatif rendah, dimana harga yang dijual ke agen sekitar Rp.26.000,-/kg padahal kalau dijual ecer dengan memanfaatkan outlet atau Media Online bisa mencapai Rp.40.000,-/kg. Sebenarnya kedua 
mitra ini saling memiliki keterkaitan untuk dikembangkan, oleh karena itu permasalahan utama yang dihadapi oleh mitra ini adalah : 1) Proses produksi pisang nangka memiliki tempat yang tidak layak dalam hal ruang kerja. Teknologi yang digunakan sangat sederhana sekali dalam hal cara pengolahan proses pengirisan menggunakan cara-cara manual; 2) Pengetahuan IPTEK belum maksimal dimiliki oleh pengrajin dan belum adanya lembaga yang memberi penyuluhan tentang IPTEK yang sesuai dengan kebutuhan pengusaha.

\section{METODE PELAKSANAAN}

\section{Proses Produksi Keripik Pisang}

Bahan baku keripik pisang adalah buah pisang. Buah pisang yang akan dibuat menjadi keripik dipilih yang sudah tua dan masih mentah agar mudah diiris, khususnya jenis pisang olahan seperti pisang kepok, tanduk, nangka, kapas, dan jenis pisang olahan lainnya. Keripik pisang dapat dibuat menjadi beberapa rasa tergantung bumbu (seasoning) yang ditambahkan. Persiapan bahan baku juga meliputi bahan baku penolong dan bahan baku tambahan seperti air dan minyak goreng.

Proses pengolahan keripik pisang secara umum yang banyak dilakukan adalah cara konvensional dan cara vakum (vacuum frying). Pengolahan dengan cara konvensional yaitu dengan mengunakan kuali penggoreng dimana kondisi bahan pangan yang digoreng terbuka dengan udara. Umumnya alat yang digunakan berupa wajan yang berisi minyak goreng, lalu dipanaskan dengan kompor atau tungku pemanas. 


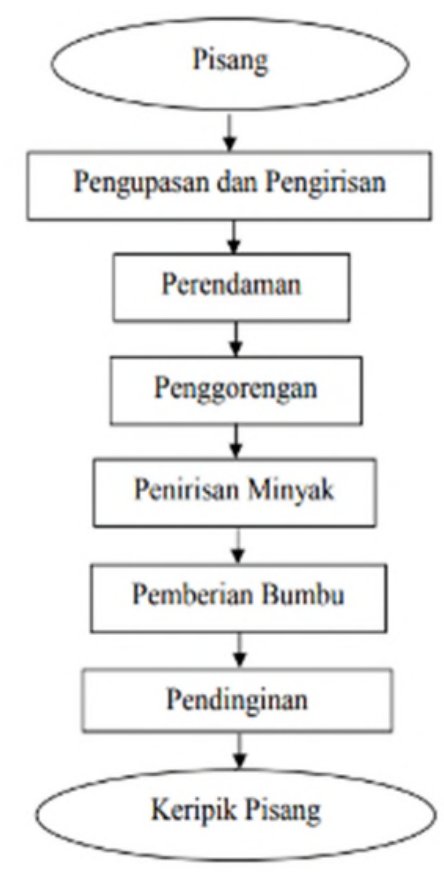

Gambar 1. Diagram alir proses pengolahan keripik pisang

\section{Mutu Keripik Pisang}

Klasifikasi karakteristik mutu bahan pangan terdapat dua kelompok, yaitu: (1) karakteristik fisik/tampak, meliputi penampilan yaitu warna, ukuran, bentuk, dan cacat fisik; kinestika yaitu tekstur, kekentalan dan konsistensi; flavor yaitu sensasi dari kombinasi bau dan cicip, dan (2) karakteristik tersembunyi, yaitu nilai gizi dan keamanan mikrobiologis. Adapun sifat mutu merupakan sifat-sifat yang langsung dapat diamati, dianalisis atau diukur dari produk. Sifat- sifat itu dapat berupa sifat fisik obyektif (susunan kimia, kadar air, kadar abu, berat dan ukuran) ataupun sifat organoleptik subyektif (rasa, bau dan tekstur).

ISO-9000 sebagai derajat dari serangkaian karakteristik produk atau jasa yang memenuhi kebutuhan atau harapan yang dinyatakan. Untuk menjamin mutu produk, di Indonesia telah ditetapkan standar mutu keripik pisang yang dikeluarkan oleh Badan Standarisasi Nasional (BSN) yaitu SNI No. 01-4315-1996. Dengan adanya standar mutu produk, maka pihak konsumen akan diuntungkan karena akan memperoleh produk dengan mutu yang baik. Standar mutu keripik pisang dapat dilihat pada Tabel 1. 
Tabel 1. Standar Mutu Keripik Pisang Menurut SNI No. 01-4315-1996

\begin{tabular}{lll}
\hline Kriteria uji & Satuan & Persyaratan \\
\hline Bau & - & Normal \\
\hline Rasa & - & Khas pisang \\
\hline Warna & - & Normal \\
\hline Tekstur & - & Renyah \\
\hline keutuhan & $\%$ & Minimal 70 \\
\hline Kadar air, b/b & $\%$ & Maksimal 6 \\
\hline Kadar lemak, b/b & $\%$ & Maksimal 30 \\
\hline Kadar abu, b/b & $\%$ & Maksimal 8
\end{tabular}

Sumber: BSN, 2007

Keripik pisang mempunyai nilai gizi cukup tinggi, terutama nilai energi dari $100 \mathrm{~g}$ keripik pisang diperoleh energi sebesar 519 kkal. Nilai energi tersebut jauh lebih tinggi dibandingkan dengan daging ternak, yang berkisar 120-430 kkal per 100 g. Nilai energi keripik pisang lebih tinggi dari pada nilai energi beras yang hanya 364 kkal. Nilai energi yang tinggi tersebut berasal dari kadar karbohidrat dan minyak yang terserap selama proses penggorengan keripik. Itulah sebabnya, keripik pisang cocok digunakan sebagai makanan pensuplai energi, khususnya ketika sedang sibuk beraktivitas.

\section{Proses Kegiatan}

Tim berkunjung ke pabrik keripik pisang nangka di Jl. Hutan Tua Dusun III B Gg. Jati No.30B Desa Limau Manis Kecamatan Tanjung Morawa Kabupaten Deli Serdang. Dalam kunjungan ini kami memperkenalkan diri dan menanyakan tentang permasalahan yang dihadapi oleh pengusaha keripik pisang nangka yang kami sebut sebagai mitra. Ternyata permasalahan yang dihadapi adalah :

- Kebutuhan mereka terhadap mekanisasi mesin pengiris dan alat peniris.

- Harga pengambilan hasil produksi oleh distributor sebagai MITRA II perkilonya adalah Rp.26.000,- kemudian MITRA II menjual ke Retail (Careefour, Alfamart, Indomaret) perkilonya adalah Rp.40.000,--

\section{HASIL KEGIATAN}

Dari hasil pelaksanaan kegiatan pengabdian masyarakat ini, luaran yang diperoleh adalah peningkatan hasil produksi keripik pisang nangka. Dengan adanya bantuan berupa alat/mesin pengiris pisang, dimana sebelum ada mesin pengirsi pisang produksi yang 
dihasilkan sebanyak 50-60 kg/hari dengan waktu kerja 8 jam/hari meningkat menjadi 150-200 kg/hari. Berikut gambar kegiatan pengabdian masyarakat di desa limau manis kecamamatan tanjung morawa.

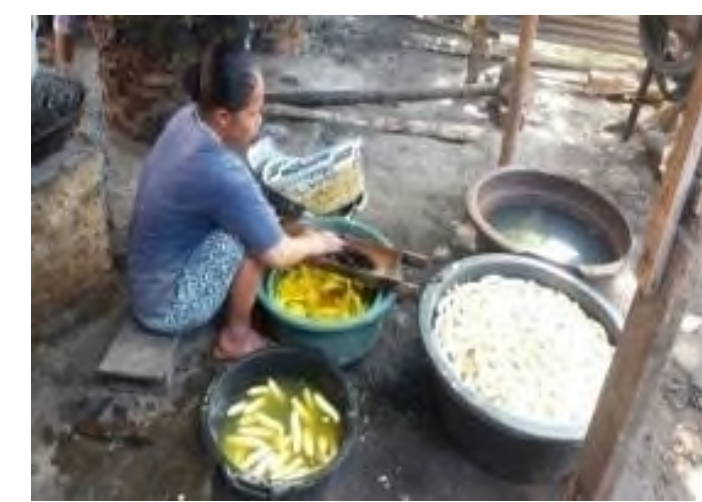

Gambar 2. Proses pengupasan dan pencucian Bahan

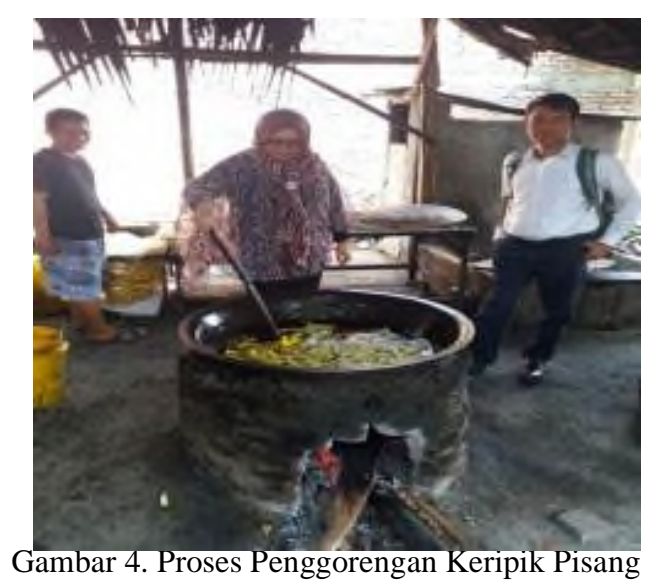

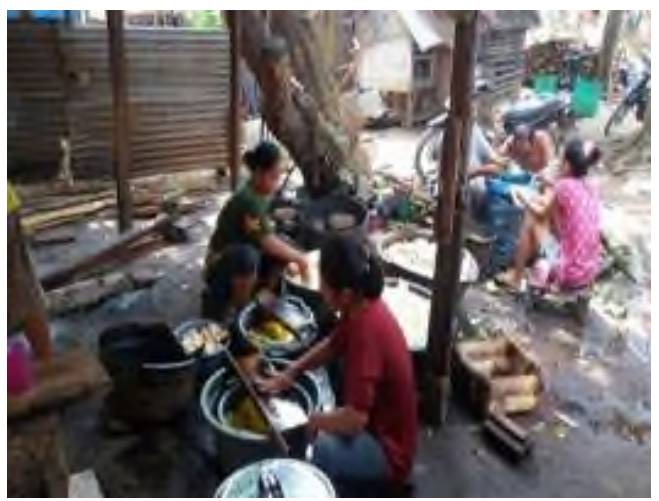

Gambar3. Proses pemotongan Pisang

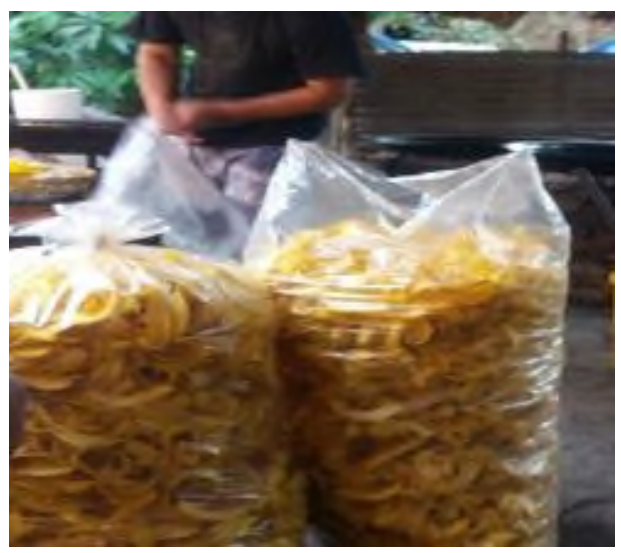

\section{PEMBAHASAN}

Penerapan Teknologi Tepat Guna (PTTG), yaitu melakukan renovasi tempat usaha yang meliputi : Tempat kupas, Tempat iris, Tempat penggorengan, dan Tempat packing ; memberikan bantuan mesin yang akan digunakan yaitu mesin pengiris dan alat peniris, serta memberikan penyuluhan dan sosialisasi tentang higienisnya tempat usaha.

\section{SIMPULAN}

Fakultas Teknik UMA telah melaksanakan kegiatan Pengabdian Masyarakat dengan memanfaatkan keilmuan Teknik Sipil dan Teknik Industri dalam meningkatkan produktivitas pengolahan keripik pisang pada Sistem Manajemen Produksi dan Sistem Manajemen Pemasaran. 


\section{DAFTAR PUSTAKA}

Amsyah Hrp, M., febri, S., \& Harahap, G. (2019). ANALISIS KELAYAKAN USAHA TANI PISANG BARANGAN (Musa acuminata L.) (Studi Kasus: Kelompok tani mekar tani Kecamatan Biru-biru). Jurnal Agriuma, 1(1). doi:https://doi.org/10.31289/agr.v1i1.2329

Khafiz, K., Suswati, S., \& Indrawati, A. (2018). Peningkatan Pertumbuhan Bibit Pisang Barangan dengan Aplikasi Fungi Mikoriza Arbuskular. Agrotekma: Jurnal Agroteknologi dan Ilmu Pertanian, 2(2), 8190. doi:https://doi.org/10.31289/agr.v2i2.1627

Marzuki Hasibuan, A., Suswati, S., \& Azis, R. (2017). Efektivitas Pemberian Pupuk Organik Terhadap Pertumbuhan Anakan Pisang Yang Diperbanyak Melalui Pematian Titik Tumbuh. Agrotekma: Jurnal Agroteknologi dan Ilmu Pertanian, 2(1), 36-45. doi:https://doi.org/10.31289/agr.v2i1.1104

Muchsin, M. 2017. Peningkatan Kualitas dan Produktivitas. Journal Umpo. Journal.umpo.ac.id

Mulyadi, A.F. 2015. Peningkatan Kapasitas dan Efisiensi UMKM. Jurnal IBM.

Syahputra, A., Suswati, S., \& Indrawati, A. (2017). Pengendalian Hama Penggerek Bonggol Pisang (Cosmopolites sordidus. Germar) Dan Penggerek Batang Pisang (Odoiphorus longicollis. Olivier) Dengan Beauveria bassiana. Agrotekma: Jurnal Agroteknologi dan Ilmu Pertanian, 1(1), 69-80. doi:https://doi.org/10.31289/agr.v1i1.1108

Tjandra, S. 2014. Perancangan Mesin Pengiris Pisang untuk Home Industry. Repository IST Akprind. Repository.akprin.ac.id .sutanto_20114.

Wahyu K. Sugandi, Asep Yusuf, Ahmad Thoriq. 2017. Rancang Bangun Mesin Pengiris Talas”Jurnal Teknik Pertanian Lampung-Vol. 6, No. 1: 53-62

Wahyudin Van Gobel, Yunita Djamalu, \& Evi Sunarti Antu. 2016. Rancang Bangun Alat Pengiris Pisang. Jurnal Teknologi Pertanian Gorontalo (JTPG). 